XONOOPER, W:

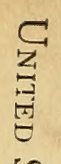$$
\text { Biographical Sketch of }
$$$$
\text { the late W: Cooper of Hud- }
$$$$
\text { son Co. N. J. }
$$$$
\sum_{i}^{\infty} \text { New York. }
$$

QH

31

C78C66

1887

SLRA 



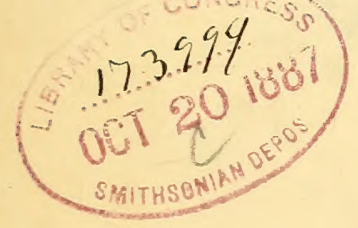

\section{BIOGRAPHICAL SKETCH}

OF THE LATE

\section{William Cooper \\ OF}

HUDSON COUNTY

NEW JERSEY 


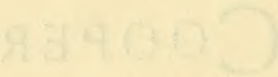


Irom the authos 



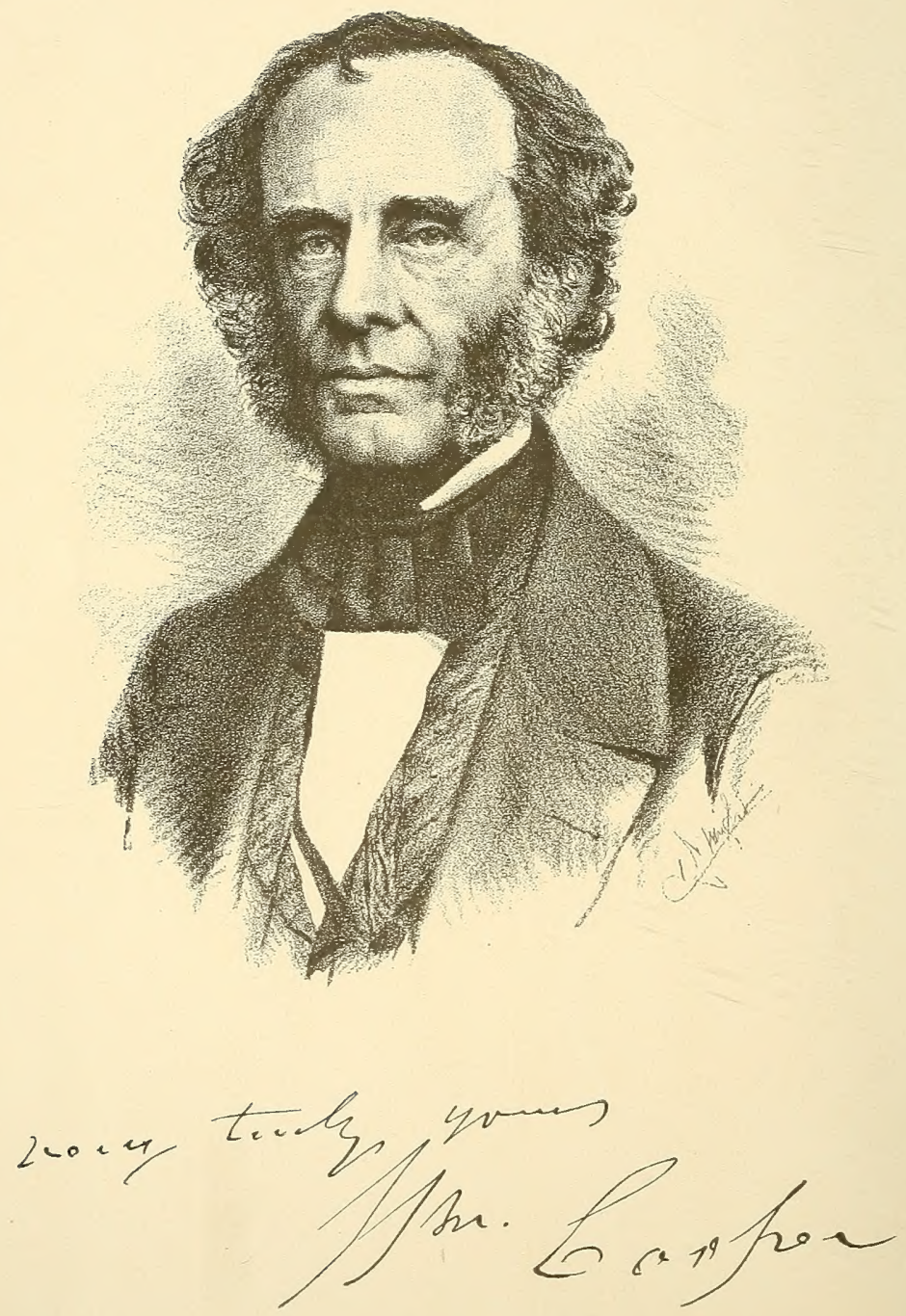


\title{
BIOGRAPHICAL SKETCH
}

\author{
OF THE LATE \\ William Cooper \\ OF

\section{HUDSON COUNTY}

NEW JERSEY

NEW YORK

GILLISS BROTHERS \& TURNURE, THE ART AGE PRESS 400 \& 402 WEST I4TH STREET 



\section{WILLIAM COOPER}

$W^{\text {ILLIAM COOPER, born about the }}$ year I798, was the son of James Cooper, an English merchant belonging to a good Yorkshire family, who, coming to New York shortly after the Revolutionary War, accumulated a comfortable fortune for that time, and died in I8or. His other sons having died in early youth, William gave up ideas of business for study of nature and for travel in Europe, which was then a rare pleasure for Americans.

His tastes seem to have been inherited from his mother, who was Miss Frances Graham, of Ulster Co., New York. When about twenty $\mathrm{Mr}$. Cooper united with a number of gentlemen of scientific inclinations in establishing the "Lyceum of Natural History," organized in 1817 , of which the distinguished physician, 
naturalist and U. S. Senator, Dr. Samuel L. Mitchill, was the first president.

Nathaniel Paulding, the poet, and William Cooper were the first secretaries of the incorporated society (1818), and Dr. John Torrey, with others known to science, the first curators.

Mr. Cooper's tastes led him to collect material in Natural History, chiefly for the Museum of the Lyceum, and to contribute his aid to older naturalists, who were investigating special branches.

Taking much interest in Botany, he was the life-long friend of Dr. John Torrey, and with a few companions helped him in gathering the material for the "Plants found within thirty miles around New York," and afterwards for the "Compendium of the Flora of the Northern and Middle States," which the author, although his senior in years and scientific experience, dedicated to Mr. Cooper "as a testimony of respect for his attainments as a naturalist, and as an expression of high esteem for his virtues."

The botanical field being already fully oc- 


\section{WILLIAM COOPER}

cupied, Mr. Cooper did not undertake any original work in it; though glad to contribute his share to the completion of the "Flora of North America," by collections, of plants and notes made in various portions of the United States. His only published article on Botany is named "Note on the habitat of Schizaa pusilla"-a plant first discovered in I8I 7 by Pursh, in New Jersey.

Astragalus Cooperi, Gray, was also discovered by Cooper at Niagara Falls, and many other contributions from new localities are attributed to him.

By the advice and encouragement of Dr. Mitchill, he resolved to make a tour in Europe to prepare himself for the study of Zoölogy and allied sciences more thoroughly than any American had yet done.

He went abroad in 1821 , and spent more than two years examining museums and libraries. He was elected the first American member of the Zoölogical Society of London ; attended the lectures of Cuvier and the other great teachers of the Jardin des Plantes in Paris; spent several months in Italy, and, 
besides acquiring a thorough knowledge of the languages of those countries, gained many scientific as well as social friends, and purchased all the books he could get relating in any degree to the fauna of America.

The Lyceum, having gained much in membership and collections, began the publication of its "Annals," the first volume appearing in I823. This and the four following volumes contain nearly all Mr. Cooper's original articles, though he is quoted in several other scientific books.

Mr. Cooper's foreign experience enabled him to take up a branch of science at that time scarcely touched except by foreign investigators - namely, the fossil bones of gigantic animals. His conclusions on these fossils are so accurate that later students have found little in them needing correction. ${ }^{x}$

The general custom of that day was for naturalists to aim at an acquaintance with all

${ }^{1}$ On the remains of the Megatherium recently discovered in Georgia. 1823 .

${ }^{2}$ Account of the discovery of a skeleton of the Mastodon giganteum in New Jersey. (Report of a committee of three, one of whom was Mr. Cooper.) 1824. 


\section{WILLIAM COOPER}

branches of natural science, and it is therefore not surprising that Mr. Cooper attempted the collection and description of all the living vertebrate animals of the United States, as well as those in the fossil condition.

For a person not robust enough to do much field work, he obtained what was then a large and valuable private cabinet, and employed other persons to aid in this work, hoping to make it useful at some future time in working up the Zoollogy of the country.

The only new bird he ever described was sent to him by his friend Schoolcraft, ${ }^{3}$ the celebrated writer on Indian history, who was then exploring towards the head of Lake Superior. Extant manuscripts by Mr. Cooper show that he might have anticipated the publication of many discoveries. Too generous in aiding others, he never received the credit his own labors deserved.

During these years Prince Charles Lucian Bonaparte was in America, and undertook the

${ }^{3}$ Description of a new species of Grosbeak inhabiting the Northwestern Territory of the United States, Fringilla (now Hesperiphona) vespertina.-Annals N. Y. Lyceum, 1825 . 
continuation of the American Ornithology of Wilson. He formed an intimate friendship for Mr. Cooper, spent much time in his society, and incorporated in his fine work the new information collected by Mr. Cooper, besides intrusting to him the correcting, in the text, of his imperfect English and the editing of the two last volumes, after his own departure for Europe in 1828 .

Mr. Cooper was glad to have so good an opportunity for publishing the results of his ornithological studies, which appeared to him insufficient to justify the expense of separate books.

Letters still in existence testify to the high regard entertained by Bonaparte for Mr. Cooper's judgment and assistance in these matters, which was further manifested by the dedication to him of the finest new species described in Bonaparte's work-the Falco Cooperi, now well known throughout scientific and other literature as "Cooper's Hawk."

The original specimen of this hawk, shot by Mr. Cooper himself in Hudson Co., New Jersey, was supposed by him to be undescribed, 


\section{WILLIAM COOPER}

but, with his usual caution, and for fear of making another synonym, he let it remain so, until Bonaparte confirmed it as being really new.

Mr. Cooper also gave the use of his specimens and notes to Audubon and Nuttall, the latter dedicating to him the "Muscicapa Cooperi," which, however, had been named $M$. borealis a little earlier. Mr. Nuttall also frequently quotes Mr. Cooper's authority as to other species, which, like this, were first obtained by him. ${ }^{4}$

It must be remembered that scientific work was, at that time, printed in America only at private expense, excepting such additions to popular works on travels, or finely illustrated books on birds, etc., as were expected to re-

${ }^{4}$ As an instance, it may be observed that Nuttall quotes Cooper as saying that "Falco Cooperi (described in immature plumage in 1828 ) bears the same analogy when adult to the adult of Falco fuscus as the young of that species does to the young of Cooperi." Audubon, however, named the adult bird Falco Stanleiz, thus subjecting himself to the charge of a lack of scientific accuracy, as he was doubtless acquainted with Bonaparte's work, and indeed felt compelled to acknowledge, in 1839 , the identity of the species. 
turn a profit to the authors and publishers by a sale beyond scientific circles.

No government publication had yet appeared devoted exclusively to science except some small reports on geology and mineralogy in relation to the economical value of certain public lands.

No college yet recognized natural sciences, except as applied to the arts or to medicine, and the investigator was obliged to pay his own expenses, besides a great part of the cost of the publication which was undertaken by the few scientific societies then existing.

Continuing meanwhile his studies of fossil bones, Mr. Cooper determined the important geological fact of the former extension of the vertebrate fauna of South America, since the tertiary age, as far north as the Middle United States. ${ }^{5}$

The abundance of large fossil bones found at Big-Bone Lick, Kentucky, which had been collected to some extent by General M. Lewis,

${ }^{5}$ Further discovery of fossil bones in Georgia and remarks on their identity with those of the Megatherium of Paraguay, 1827 . 
under the patronage of President Jefferson, and afterwards by many others, induced $\mathrm{Mr}$. Cooper to undertake a visit there in 1828 , chiefly at his own expense, traveling across the Alleghanies, which were then as wild as the Rocky Mountains are now, in so far as the voice of the iron horse had not yet startled nature in their recesses.

With one assistant he made the journey in his own conveyance, making collections and observations of various kinds on the way, and spending some weeks at Big-Bone Lick, obtained much information and many specimens. The chief part of these were afterwards described in an article published in the American Monthly Journal of Geology. ${ }^{6}$

His botanical collections were contributed to Torrey and Gray's "Flora of North America," and the other collections went to the New York Lyceum of Natural History.

Later on Mr. Cooper visited Albany and Troy, where active scientific workers were already forming societies under the patronage of the Van Rensselaer family, Gov. De Witt

${ }^{6}$ Observations on Big-Bone Lick, I83I. 
Clinton and others. Afterwards he married and settled in his native city-New Yorkwhere, for some years following, his house was the resort of all interested in science, foreigners as well as Americans; and he devoted considerable time to making collections and descriptions of the living animals of the State, anticipating a future demand for general works on the subject. ${ }^{7}$

He found little more material for research on fossils, only one more article appearing on that subject under his authorship, ${ }^{8}$ but he continued to employ collectors in all branches of Zoölogy.

In 1838 considerations for his own health

'Mr. Cooper's father-in-law was Mr. E. Wilson, Jr. (known to that generation as Squire Wilson), of Troy, N. Y., where his ability as a lawyer, his kindness of heart, and his ever-flowing wit and humor are well remembered.

Squire Wilson was called by the countrymen of that vicinity "the Honest Lawyer," and the children of Troy would leave their play and run to receive a smile and merry word from "Gran'pa," as every one called him, when they saw, advancing on the street, his tall, commanding figure and handsome, benevolent face, with its halo of silver hair.

${ }^{8}$ A Report on some Fossil Bones of the Megalonyx, from Virginia, 1833 . 
and that of his family induced him to leave New York for a country life on his farm in New Jersey, on the banks of the Hudson, now the site of the village of Guttenberg. The same year the Lyceum published his first monograph relating to New York zoölogy, and two papers on species of bats found beyond the limits of the State. 9 10 хт

The investigation of this, one of the most difficult orders of the class Mammalia, was made first in accordance with the scientific classification then prevailing; and though collecting much towards a continuation of the subject, he never published more in his own name.

He was offered the pleasant and profitable employment of preparing the Zoölogy for the great work on the Natural History of New York, but feeling that he could not do justice to the subject, not being in sound health, and

${ }^{9}$ Description of five species of Vespertilio that inhabit the environs of the city of New York.

${ }^{10}$ On two species of Molossus inhabiting the Southern United States.

${ }^{11}$ On two species of Plecotus inhabiting the United States Territories.

(Reprinted as "Researches on the Cheiroptera.") 


\section{BIOGRAPHICAL SKETCH}

living at what was in those days an inconvenient distance from the libraries and museums of the city, he declined it, and his friend, Dr. James E. DeKay, who undertook the work, had the use of the materials which Mr. Cooper had collected.

As an example of his style of scientific work, the articles on the bats exhibit great accuracy and thoroughness, only seven species being admitted by him as well determined, out of twenty-four previously named from this country, adding two as new species, viz., Plecotus Townsendi and Molossus fuliginosus (included under Nyctinomus nasutus, by Allen).

With the few specimens then obtainable, many of them in poor condition, it was im. possible to identify more from the imperfect descriptions of the older authors; but he thought seven of the others might prove good species. Later students, however, have only identified two of them, finding little of $\mathrm{Mr}$. Cooper's work requiring alteration.

Finally, various cares and the want of robust health prevented the continuation of scientific studies, and Mr. Cooper found it 
best to part with most of his collections and library, which could not be well preserved when not used. But the chief object of country life-the health and well being of his family-was gained.

In 1853 , his eldest son having graduated at the College of Physicians and Surgeons, and his other children fast growing up, Mr. Cooper sold his farm and removed to Hoboken, desiring again to enjoy the advantages of city life, and also to remain in the neighborhood in which he had lived so long that it had become more homelike than the changed and changing city of New York. For several years he occupied the honorable office of Associate Judge of the District Court, attending the quarterly sessions, and, though not a lawyer, giving universal satisfaction.

He was now again able to do something in natural science, but as his former fields of labor were filled by numerous workers, who enjoyed, through societies or governments, the aid of public funds such as no individual could afford, he resolved to make a collection 


\section{BIOGRAPHICAL SKETCH}

of shells, which could be obtained more easily and better in New York than anywhere else, were easy to preserve and always of value for ornament and study.

The restraint of a limited income did not prevent the accumulation of a very fine cabinet, chiefly of excellent specimens, during the ten remaining years of his life. By thoroughly identifying and labeling these, he increased their value so that they were eagerly bought by the late Prof. Stimpson for the Chicago Academy of Sciences, after Mr. Cooper's death.

The collections of shells made by his son, Dr. J. G. Cooper, and others on the west coast of North America were made the subject of a report forming one of the Pacific $R$. R. series for I860, the last work written by Mr. Cooper and intended only as a preliminary article.

Mr. Cooper himself collected during these years on the coasts of Maine and Nova Scotia, where he made dredging excursions with his second son, William, during the summers of 1858 and 1862 , obtaining numerous rare 
mollusks, etc., as quoted in Binney's edition of the Invertebrates of Massachusetts, I870; also at Greenport, L. I., and other places in the vicinity of New York, and at the Bahama Islands.

The results of Mr. Cooper's former collections in other branches, although chiefly published long before this time, and investigated by Prof. Baird, furnished two new species, remarkable when compared with the extensive series of specimens obtained by the Government expeditions.

One was a new genus of field-mouse allied to the Lemmings, founded on two very imperfect specimens, probably collected in the Northwestern States by Schoolcraft or some other unskilled taxidermist.

It was named "Myodes Cooperi" by Baird in I 857 , but between ' 57 and ' 67 it was obtained in great numbers from Illinois and northwest to Alaska, proving to be of a new genus (Synaptomys Baird), of which Coues writes, in I877, that it is "the most remarkable genus of the sub-family; one singularly combining the peculiarities of two other widely separated 
Arvicoline genera." ("Monograph of North American Rodentia," page 228.)

It is no wonder that Mr. Cooper, with a cautious desire for accuracy, left undescribed such imperfect and puzzling specimens in hope of some day obtaining means for their proper comparison and identification.

The other species was a bird of the sandpiper family, shot May 24, I833, at Raynor South, Long Island, and also kept, in hope of obtaining more before describing it as a new species of that very difficult and obscurely determined group. But no second specimen has ever been obtained, and now, after more than twenty years' test, the name of Tringa Cooperi, Baird, seems likely to remain, as given to it in the Pacific R. R. Report on Birds, page 716 , and in Baird's Birds of North America.

In disposition Mr. Cooper was retiring and free from personal ambitions, perhaps too apt to give way to the desires and interests of others, as he had never been trained in the "struggle for existence," or else, allowing for his delicacy of constitution, his early 


\section{WILLIAM COOPER}

promise of distinction in the scientific world would probably have led him into positions of high honor.

Notwithstanding his extreme gentleness, he was a "good hater" of dishonesty, oppression, injustice, and all else that dishonors man. Clear in perception, sound in reason, full of self-control and well informed on all points, he was in advance of the age in his opinions on politics and the progress of science, and his judgment was deferred to, even by those whose views differed from his, but who in the course of time generally found he was right.

$\mathrm{He}$ served for years as vestryman in St. Paul's P. E. Church in Hoboken, and was a true example of a Christian gentleman. He had great fondness for animals; cruelty to them roused him to an indignation and resistance which personal wrongs would hardly excite; and one of the last great pleasures of his life was the rising up of Henry Bergh to be the "Great Heart" of these helpless, suffering companions of our pilgrimage through life.

His gradually failing health resulted in en- 


\section{WILLIAM COOPER}

largement of the heart, from which he died, April 20, I864, and, we may believe, entered that region where abide the just, the merciful, and the pure in heart, and where the innumerable wonders of creation shine in the clear light of eternity. 




